\title{
Key capabilities for frugal innovation in developed economies: insights into the current transition towards sustainability
}

\author{
José Ángel López-Sánchez ${ }^{1}$ [D - María Leticia Santos-Vijande²
}

Received: 5 July 2021 / Accepted: 25 November 2021 / Published online: 10 January 2022

(c) The Author(s), under exclusive licence to Springer Japan KK, part of Springer Nature 2021

\begin{abstract}
Frugal innovation has become a requirement for success in resource-scarce environments, a situation that the COVID-19 pandemic has exacerbated. In this context, the literature has developed several frugal innovation approaches for promoting sustainability, but there is no a widely accepted theory nor a predominant paradigm given the incipient and relatively new nature of a research domain that requires further studies. There is also a high potential for under-exploited markets, represented by low-income consumers who no longer concentrate on developing countries and where there is a cumulative number of consumers with minimal spending capacity, rising income distribution inequality, and the increasing polarization of wealth and risk of poverty. This paper contributes to the literature by examining from a Resource-Based View perspective, the critical role of two key organizational capabilities, namely market-focused learning and organizational ambidexterity, to develop firms' innovation capability in low-end markets due to the unique characteristics of these markets. In doing so, the study employs partial least squares structural equation modeling (PLS-SEM) with a sample of 190 manufacturing firms to provide empirical support to our theoretical predictions that establish that: (1) market-focused learning capability drives organizational ambidexterity, (2) market-focused learning capability and organizational ambidexterity foster organizational innovation capability, which, ultimately, affects cash flow, and (3) market-focused learning capability has a stronger effect on organizational innovation capability in low-end markets. Contrary to our expectations, organizational ambidexterity has a stronger impact on organizational innovation capability in non-low-end markets, considering that this is the first step to shed light on this issue.
\end{abstract}

Keywords Frugal innovation · Sustainability · Low-end markets · Market-focused learning · Organizational ambidexterity · Organizational innovation capability

\section{Introduction}

Frugal innovation remains until today without a "single definition" (Hossain 2020, p. 1) or a "common understanding and conceptualization" (Von Janda et al. 2020, p. 2),

Handled by Faik Bilgili, Erciyes University, Turkey.

José Ángel López-Sánchez

jangel@unex.es

María Leticia Santos-Vijande

1santos@uniovi.es

1 Facultad de Ciencias Económicas y Empresariales, Universidad de Extremadura, Avda. de Elvas s/n, 06071 Badajoz, Spain

2 Facultad de Economía y Empresa, Universidad de Oviedo, Avenida del Cristo s/n, 33071 Oviedo, Spain although it may constitute an indispensable requirement for firms' success in resource-scarce environments while also driving sustainable development (Albert 2019; Köhler et al. 2019; Iqbal et al. 2021; Winkler et al. 2020; Ekins and Zenghelis 2021; Elf et al. 2021; Hossain et al. 2021; Pinkse and Bohnsack 2021; Saha et al. 2021; Wigboldus and Jochemsen 2021). Thus, recent studies underline that frugal innovation is connected with the idea of "developing resource-scarce but quality solutions that are cheaper than the existing products" (Hossain 2020, p. 1) and can be considered a first step option for a sustainable future (Van Mossel et al. 2018; Köhler et al. 2019; Ekins and Zenghelis 2021; Hossain et al. 2021; Wigboldus and Jochemsen 2021). However, the concept of frugal innovation is not limited to the idea of costs reductions (Weyrauch and Herstatt 2017). Frugal innovation redesigns products and services to achieve optimal performance while preserving core 
functionalities, often exceeding expectations and even leading to breakthrough improvements (Bhatti et al. 2018). Thus, O'Callaghan et al. (2020) and Hossain et al. (2016) argue that frugal innovation can evolve, disrupting the market and causing changes in the way firms traditionally compete, and it may also diffuse, for example, from low-income market segments to high-income ones (Clausen and Fichter 2019). Furthermore, frugal innovation can play a significant role by contributing to sustainable societal, economic and environmental development (Roscaet al. 2017; Albert 2019) by providing valuable and affordable solutions to low-income consumers in both developed and non-developed markets (Winkler et al. 2020), which reinforces the current relevance of this type of innovation (Hossain 2020; Iqbal et al. 2021). Thus, many authors consider frugal innovation to be environmentally friendly basically because it seeks to economize on the use of energy and material resources, both in the design of goods and services and in their production and marketing (Bocken 2020; Hossain et al. 2021).

In addition, several studies claim that frugal innovation generates a "low carbon footprint, or a smaller ecological footprint than usual, and has fewer emissions" (Albert 2019, p. 6). Nevertheless, the main priority of frugal innovation is fostering social and economic sustainability (Rosca et al. 2017; Wohlfart et al. 2016). The effect of frugal innovation on social sustainability comes from the potential improvement of the standard of living of low-income consumers by creating cost-saving opportunities and reducing spending (Reinhardt et al. 2018; Hossain 2020). Saving costs for these segments of consumers frees up resources to improve their access to more products and services, to leisure or to activities that promote their individual development, which also enhances their chances of advancement and integration (Khan 2016; Iqbal et al. 2021). Frugal innovation may also influence economic sustainability because as it provides a higher level of value to low-income consumers, there is an opportunity to increase firms' sales and profits and expand its customer base (Bocken et al. 2014; Clausen and Fichter 2019). However, despite the potential benefits of frugal innovation to sustainable development, our understanding of how to foster frugal innovation is limited, and empirical studies in this research field are still scarce (D'Angelo and Magnusson 2020).

The phenomenon of frugal innovation is also recognized by academics and practitioners as gaining more relevance in developed economies. In the United States, since the 1970s, the percentage of middle-income households has been gradually declining, largely due to an increase in the number of households with low or very low incomes. Although the growing inequality of income distribution in the economies of developed countries is caused by a wide variety of factors, about which there is no unanimity among experts, the result of this process, in which Europe also participates, has been an increasing polarization of wealth and of the spending power of individuals. Over the last two decades, this trend has become more pronounced and has had a far-reaching impact on behavioral patterns in Western markets, where an increasing number of consumers have very limited spending power. Thus, low-income consumers no longer predominantly concentrate on developing countries and represent an under-exploited market (Reinhardt et al. 2018; Albert 2019; Hossain 2020). In this respect, the COVID-19 pandemic has also contributed to a significant exacerbation of poverty in developed countries (IMF 2020).

Despite the low purchasing power of low-end consumers, the overall expenditure in low-end markets can be large enough to make these markets attractive for many firms. Moreover, today's low-income consumers are tomorrow's middle class. In fact, firms can build a new, substantial consumer base if they specifically seek out low-end consumers and promote brand loyalty within this market segment (Gordon and Hodgson 2017). Although they are highly pricesensitive, low-income consumers also demand new products and services. Thus, innovation constitutes a requirement to succeed in low-end markets.

Recent studies suggest that low-end innovation may require different capabilities than regular innovation and that the capabilities that guide low-end innovation success may differ in relevance across different contexts (Reinhardt et al. 2018; D’Angelo and Magnusson 2020; Iqbal et al. 2021). However, empirical evidence on frugal innovation is still limited, and moreover, for developed economies. Accordingly, this article contributes to the literature by examining the critical role of two key organizational capabilities, namely market-focused learning and organizational ambidexterity, to develop firms' innovation capability in lowend markets, providing insights into "the current transition towards sustainability" (Van Mossel et al. 2018, p. 44). The market-focused learning concept is an emerging construct that underlines the relevance of adopting a learning perspective to improve firms' market orientation and ensure, in this way, the organization-wide generation, dissemination, and responsiveness to market intelligence (Gebhardt et al. 2019). Organizational ambidexterity allows firms to achieve two main objectives: to be efficient in their current businesses, taking advantage of their present knowledge, and to be flexible in acquiring new knowledge to take advantage of future opportunities (Benitez et al. 2018; Ferreira et al. 2020).

From a Resource-Based View, we first propose that firms with higher levels of market-focused learning and organizational ambidexterity will develop a greater innovation capability (Benitez et al. 2018; Damanpour et al. 2018; Simao and Franco 2018). We then argue that market-focused learning and organizational ambidexterity are even more suitable to foster firms' innovation capability in low-end markets. More specifically, after reflecting on the 
special characteristics of low-end markets, we argue that market-focused learning and organizational ambidexterity make it possible to better meet the innovation requirements of low-end markets and to reconcile differentiated product development with low-cost innovation (Birkinshaw et al. 2016; Rosca et al. 2017; Reindhart et al. 2018; Hossain 2020).

Therefore, with this piece of research, we attend Reinhardt's et al. (2018) and Hossain's (2020) recent calls for a better understanding of underserved low-income consumers. First, we identify two specific organizational capabilities (market-focused learning and organizational ambidexterity) that promote frugal innovation. The role of these capabilities in frugal innovation has not been studied in the past, while further efforts are required to broaden our knowledge and gain additional insights into promoting frugal innovation. Moreover, our study provides insights on the relationship between market-focused learning and organizational ambidexterity, which has been barely addressed in previous research. Thus, from a theoretical and qualitative perspective, Perters and Buijs (2021) underline the need to adopt a strategic ambidexterity strongly based on organizational learning to foster green innovation. Only recent studies, such as Chen and Liu's (2018) and Yang's et al. (2020) focus on this relationship but do not incorporate firms' performance variables or product innovation-related outcomes. Second, we provide empirical evidence referred to developed economies where there is a cumulative number of consumers with minimal spending capacity due to the rising income distribution inequality (Winkler et al. 2020). Third, there is no theoretical framework that examines the impact of frugal innovation on an objective performance measure, cash flow, which is considered to capture variation in firm performance better than other accounting-based measures (Vorhies et al. 2009) (Fig. 1).

\section{Theoretical framework and hypotheses development}

\section{Innovating for low-end markets}

Given the growing prevalence of two different types of consumers in developed countries (affluent consumers with rising income versus low and middle-income consumers with stagnant incomes), consumer product companies need to develop specific products and strategies for targeting the low-end segments in addition to the premium segments and the middle market (Reinhardt et al. 2018). In fact, lowincome segments are profitable and have witnessed intensifying competition among major retailers (Gordon and Hodgson 2017).

Low-end consumers are willing to buy new products and services as regular buyers. Moreover, frugal innovations can drive growth and prosperity for both firms in emerging and developed markets, especially since the gap between lowend markets in emerging and developed countries is narrowing (Prahalad 2019). Thus, frugal innovation is a currently important, global consumer topic. Drawing on Reinhardt's et al. (2018, p. 770) view, frugal innovations are "new products or services that expand a market by addressing consumers with a low willingness or ability to pay (WTP)" as a low-end market. In other words, frugal innovations are new products or services that enable current non-customers to enter the market due to their lower WTP. Frugal innovations, therefore, extend and expand the available product set for low-end customers. This view on frugal innovations coexists with other approaches as there is no widely accepted theory nor a dominant paradigm due to the relatively new existence of this research domain (Reinhardt et al. 2018; Hossain 2020; Von Janda et al. 2020).

Recent studies suggest that frugal innovation requires different capabilities than regular innovation and that these

Fig. 1 Conceptual model

Key Capabilities

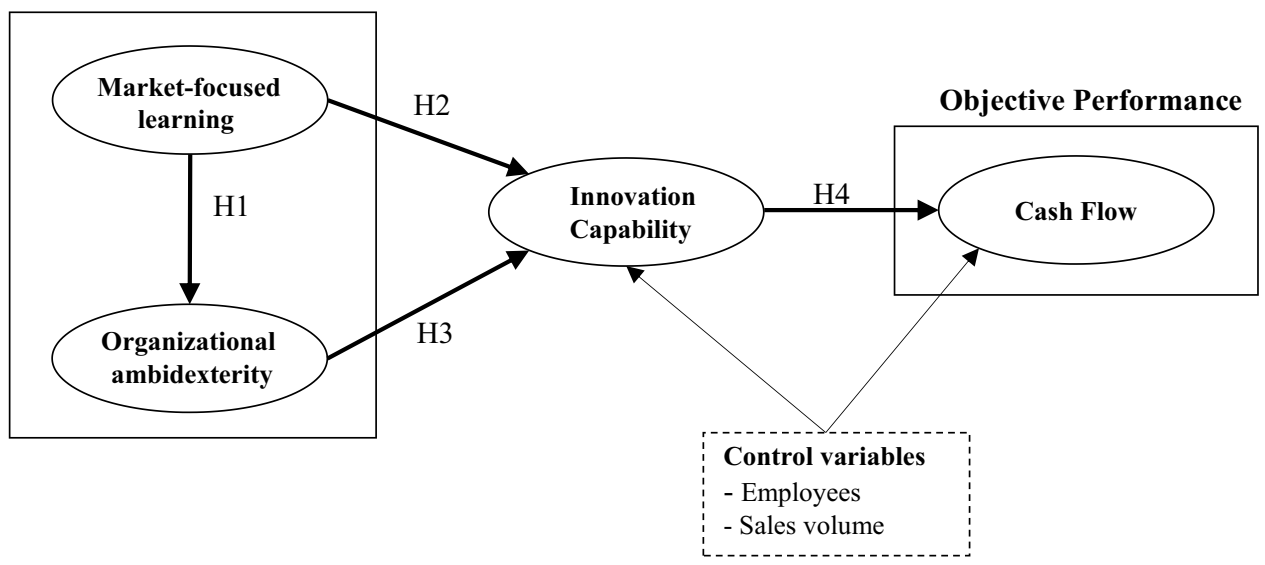


capabilities that influence frugal innovation success may differ in relevance across different contexts (Reinhardt et al. 2018). Therefore, to understand how to develop a firm's ability to innovate in low-end markets, we need to identify critical aspects of how low-income consumers can be served profitably, or the unique features of low-end markets. In this respect, the 4 A's model (ATKearney 2007), together with the works of Bocken et al. (2014), Ernst et al. (2015), Reinhardt et al. (2018), and Hossain (2020), provide valuable insights about four distinct characteristics of low-end markets. First, affordability is the most pressing issue in the low-income consumer sector as people have little chance of saving money for large investments. Managers report that affordability is one of the most important criteria for new product success, although it is challenging to implement frugal innovation profitably. Firms with a strong ability to reduce costs and offer favorable cost-benefit ratio solutions are more likely to develop valuable products for low-end markets (Clausen and Fichter 2019).

Second, availability for frugal innovation may require that distribution channels experiment with substantial modifications. Low-end customers cannot buy large quantities due to financial constraints, so it is necessary to have a distribution system that allows them to buy frequently and with low volume. A strong market sensing ability becomes especially useful in this endeavor. Third, many low-income consumers retain their traditional roles, religious motivations, and other unique cultural factors regarding acceptability. Therefore, understanding their daily lives and their specific needs is very important. Acceptability comes from innovative thinking and a deep understanding of the local needs of low-income consumers. Moreover, in many cases, low-end markets are ambiguous, which means that low-end customer needs are particularly fuzzy and open to multiple interpretations. Accordingly, companies with strong marketfocused learning are more likely to develop valuable products for low-end markets.

Finally, awareness, due to the lack of traditional advertising in the lives of many low-income consumers, can also be a challenge. Connecting with different stakeholders, including the leaders of local communities, can be a creative way to increase awareness among low-end consumers and improve innovation acceptance. Relationships with local partners are helping to build awareness and, in most cases, create or enhance distribution capabilities.

In short, innovation for low-end markets requires developing new products and services bearing in mind the reduced purchasing power of their members and its particular characteristics. Therefore, reducing costs is imperative, as well as developing alternative ways to design and commercialize the company's offer, preserving core functionalities from the consumers' perspective and providing superior value. Bearing in mind these considerations, in the next section, we justify the relevance of organizational ambidexterity and market-focused learning capability to develop the firm's innovation capability and foster performance, as well as how this effect is improved in low-end markets.

\section{The role of market-focused learning, organizational ambidexterity and innovation capability in low-end markets}

Learning is an organizational capability that continuously allows firms to properly process available knowledge to adapt organizational behavior to changes in their competitive context. In this way, organizations capable of developing market-focused learning naturally develop adjustment and continuous improvement processes to respond successfully to the discontinuities generated by market dynamics (Weerawardena 2003; Damanpour et al. 2018; Yang et al. 2020). In other words, business organizations, faced with increasingly dynamic and complex markets, need more than ever to manage appropriately the market knowledge acquired internally and externally to develop a learning process that allows them a rapid and proactive adaptation to constant changes in the market to provide superior value (Gebhardt et al. 2019; Liang and Frösén 2020; Simao and Franco 2018; Weerawardena et al. 2020). In this sense, a superior market-focused learning capability improves the firm's ability to outperform the competition in identifying new market trends, competitors' actions and changing customer needs, which leads to improved performance and constitutes a source of competitive advantage (Chen and Liu 2018; Liang and Frösén 2020; Yang et al. 2020).

Simultaneously, firms face the challenge of taking advantage of the opportunities available in their current markets, together with the need to guarantee their future competitiveness by renewing their skills and market offerings accordingly. Ambidextrous organizations can operate in both scenarios. They can exploit their current resources and capabilities to ensure their short-term viability while at the same time exploring the development of new skills to cope with market-changing demands, benefit from future market opportunities, and proactively seek future growth (O'Reilly and Tushman 2011; Vrontis et al. 2017; Benitez et al. 2018; Clauss et al. 2020; Christofi et al. 2021). Thus, exploration is related to the search for new knowledge, experimentation of new alternatives, and the assumption of risks and discovery (March 1991; Chebbi et al. 2015; Faridian and Neubaum 2021). Exploitation focuses on the use and optimization of all existing resources and capabilities in the firm to maximize organizational performance, increase levels of quality and reliability, reduce costs, and improve levels of market satisfaction with the existing firm's product and services (Winterhalter et al. 2016; Malik et al. 2019). 
In this context, we can argue that market-focused learning is an organizational capability that allows firms to properly process available knowledge to adapt organizational behavior to changes in their competitive context on an ongoing basis and develop an ambidextrous behavior to attain a sustainable competitive advantage (Vorhies et al. 2011; Von Mossel et al. 2018; Van Welie et al. 2019; Yang et al. 2020). It is reasonable to expect that higher levels of market-focused learning will favor exploration processes and the development of new skills beyond the firm's current boundaries, promoting radical innovations and developing products and services for emerging markets (Zhang et al. 2015; Huang and Yong-Hui 2017; Weerawardena et al. 2020). Higher levels of this learning also favor the understanding and response to agents' perceptions and behaviors within a given market structure, allowing the exploitation of existing knowledge and the development of incremental innovations (Fang et al. 2010; Van Mossel et al. 2018). However, empirical evidence in this respect is still scarce (Peter and Buijs 2021). Nevertheless, we propose:

H1. There is a positive relationship between marketfocused learning and organizational ambidexterity.

Likewise, market-focused learning is expected to enhance innovation capability. In fact, the lack of new, valuable and external information can be considered one of the major inhibitors of innovation. Cohen and Levinthal's (1990) seminal paper points out this issue in the sense that, together with the firm's R\&D activity, the ability to recognize market information, assimilate it and apply it for commercial purposes is critical for innovation activities. In other words, the emergence of innovation is conditioned by the firm's ability to acquire new market knowledge (Weerawardena , 2003; Damanpour et al. 2018; Van Welie et al. 2019). However, although the importance of market intelligence is widely accepted, how managers can ensure the organization-wide generation, dissemination, and responsiveness to market intelligence remains a persistent challenge (Yang et al. 2020). In this context, the market-focused learning concept constitutes an emerging construct that reinforces the relevance of adopting a learning perspective to improve firms' market orientation and achieve this goal (Gebhardt et al. 2019; Liang and Frösén 2020). In fact, innovation can be understood as a learning process through which members of an organization share tacit knowledge and transform it into explicit knowledge in the form of new products and services (Simao and Franco 2018; Mendoza-Silva 2020). Thus, the academic literature confirms that the organizational learning capability reinforces the intensity and degree of novelty of firms' innovation capability (Tamayo-Torres et al. 2016; Weerawardena et al. 2020). A superior market-focused learning capability, therefore, is expected to improve the firm's ability to outperform the competition in responding to changing customer needs (Yang et al. 2020). The above arguments lead us to the following hypothesis:

H2. There is a positive relationship between marketfocused learning and organizational innovation capability.

A higher level of organizational ambidexterity is also considered to drive a higher level of organizational innovation capability. The literature shows that ambidexterity allows for competitive advantage as the organization can cope with and lead both incremental and disruptive changes (Jansen et al. 2009; Benitez et al. 2018; Van Welie et al. 2019; Venugopal et al. 2020). Through ambidexterity, the firm seeks to be competitive, in the short term, through exploitative or incremental innovation and, in the long-term, through exploratory, disruptive or radical innovation (Andriopoulos and Lewis 2009; Wu and Chen 2020). Specifically, exploitation is mainly linked with incremental innovation in products and processes and the achievement of short-term organizational results. The exploration dimension, however, is associated to a greater extent with the development of more radical innovations and the search for or creation of new businesses for the firm, which in turn implies obtaining longer-term results that may be most uncertain, although they also carry more significant profit potential (Winterhalter et al. 2016; Ferreira et al. 2020). If a firm undertakes only exploitation strategies, it may be left out of the market due to a lack of innovation in the medium term. Simultaneously, if it only focuses on exploration strategies, its financial viability may be compromised. Hence, recent research reinforces the idea that ambidextrous firms can achieve higher innovation levels in the medium and long term (Benitez et al. 2018; Ferreira et al. 2020) although more empirical evidence in this research field is still required (Fu et al. 2021). Therefore, we posit:

H3. There is a positive relationship between organizational ambidexterity and organizational innovation capability.

It is further supposed that higher levels of organizational innovation capability resulting from the aforementioned key capabilities' influence (market-focused learning and organizational ambidexterity) make it possible to obtain higher business performance levels. In particular, the firm's innovation capability prevents natural obsolescence by including cutting-edge technologies into its market offerings, developing radically new products or services, and/or reconfiguring the existing ones to make them more appealing from a market approach (Crossan and Apaydin 2010). This capability is a keystone in determining a firm's profitability and growth potential, as it involves tacit knowledge not easily imitated or appropriated by competitors, which constitutes an isolating mechanism of a firm's advantage (Prahalad and Krishnan 2008; Teece et al. 2016). Furthermore, a firm's innovation capability allows entering new markets, serve new market segments and seize new market opportunities; thus, the 
firm can increase its sales, profits, and market share, i.e., business growth. This research is interested in a specific objective performance outcome as a financial performance measure: cash flow. In fact, cash flow "is less influenced by accrual accounting methods and may be less sensitive to commonly used accounting manipulations... is better able to capture variation in organizational performance than other accounting-based measures" (Vorhies et al. 2009, p. 1316). We accordingly hypothesize the following:

H4. There is a positive relationship between organizational innovation capability and cash flow.

Finally, apart from the above-stated hypotheses, we are interested, as suggested by the literature, in hypothesizing that the influence of two key organizational capabilities (market-focused learning and organizational ambidexterity) is more suitable to impel firms' innovation capability in low-end markets than in non-low-end markets (Birkinshaw et al. 2016; Rosca et al. 2017; Reindhart et al. 2018; Hossain 2020). Precisely, we can highlight that market-focused learning emphasizes understanding and responding to customers' needs, i.e., allowing the firm to adapt its products and services to customers' expectations (Weerawardena 2003). Successfully marketing products at lower prices means that the firm can identify its customers' essential needs (SantosVijande et al. 2012b). Lower-priced products must sacrifice some of their features by emphasizing cost reduction, using fewer resources, and prioritizing efficiency (Bocken et al. 2014; Reinhardt et al. 2018; Clausen and Fichter 2019; Hossain 2020); therefore, knowing accurately what the market requires is essential to innovate successfully in low-end markets. Carefully identifying the market needs and expectations is more necessary in a low-end context since customers' characteristics move away from the product category's average customer profile. Innovation acceptability in lowend markets is contingent on the firm's ability to understand low-end consumers. Learning about the market can also help identify valuable market partners to build alliances and favor innovation awareness and availability. As a result, marketfocused learning may be especially valuable for developing cost leadership strategies, build acceptability and awareness conveniently. Hence, we expect that:

H5. Market-focused learning has a stronger effect on organizational innovation capability in low-end markets.

On the other hand, Reinhardt et al. (2018) underline that firms serving low-end markets need to develop the ability to innovate their inputs and processes to significantly reduce costs during the development of new products and services. Accordingly, those organizational capabilities that help firms innovate and deploy a cost leadership strategy, which concentrates on strict cost controls and efficiency in all phases of operations (Porter 1980), are likely to be especially useful in developing an organizational innovation capability in lowend markets. Organizational ambidexterity allows firms to reconcile differentiated products' development with low-cost innovations (Birkinshaw et al. 2016; Van Welie et al. 2019). In fact, exploitation activities focus on refining the available knowledge and the improved understanding of the firm's operations. In this way, firms can accomplish their objectives more efficiently, reduce complaints, reworks, defective products, and waste, diminishing their production costs (Lapersonne et al. 2015). Even exploration activities can help identify how to improve new products and processes and ultimately decrease cost (Herzallah et al. 2017). From this perspective, ambidexterity allows achieving cost leadership advantages in product innovation and can be especially beneficial to develop the firm's innovation capability in lowend markets. Stated more formally:

H6. Organizational ambidexterity has a stronger effect on organizational innovation capability in low-end markets.

\section{Methods}

\section{Sample and data collection}

To test the set of hypotheses, we contacted a private foundation that promotes innovation, which gave us access to a database of 987 Spanish manufacturing firms. Firms' managing directors are considered as the key informant in each sampling unit as they are in the best position to provide critical insights from a multitude of areas and departments, and it is easier for them to know the information to be reported on essential aspects related to organizational processes and outcomes. The average experience of key informants who finally participated in the study was 12.5 years, thus increasing the validity of the variables' measurements (Santos-Vijande et al. 2016). The managing directors were contacted via email, explaining the study's purpose and the anonymity of their response in case they agreed to participate. A total of 190 valid responses were received, equivalent to a response rate of $19.25 \%$. We also checked that non-response bias was not a problem as there were no significant mean differences between early and late respondents.

We also controlled for common method variance (Podsakoff et al. 2012). Regarding the study design (ex-ante), we established a psychological separation between predictor and criterion variables, respondents remained anonymous, and we emphasize the relevance of answering the questions truthfully. Concerning the statistical remedies (ex-post), on the one hand, we carried out Harman's single-factor test and found that the majority of the variance was not captured by one factor. On the other hand, we employed a marker variable approach, based on Lindell and Whitney's (2001) work, to measure a weakly related construct, represented empirically by the item: "I am satisfied with life". To conclude, we do not have a problem with common method variance. 


\section{Measurement scales}

We have used multi-item measurement scales to measure the theoretical constructs of organizational ambidexterity (exploitation and exploration), market-focused learning, and innovation capability via seven-point Likert scales (Table 1). The organizational ambidexterity scale is assessed to exploit the most immediate results and explore new opportunities (Lubatkin et al. 2006; Zhang et al. 2015; Malik et al. 2019; Faridian and Neubaum 2021). The exploitation dimension focuses on the use and optimization of all the firm's resources and capabilities. In fact, the aim is to measure the degree to which the firm maximizes the organizational functioning based on the available knowledge, maximizing customer satisfaction with the firms' market offer, improving both the technical quality and the reliability of the products and services provided to the market. The exploration dimension is related to the search for new knowledge, with the assumption of risks and discovery (March 1991), emphasizing the scale developed on aspects related to searching for creative ways of satisfying customers' needs. The concept of organizational ambidexterity has also been defined as the conjunction of the ability to align with the organization's existing objectives, thus fulfilling the pre-set strategy, and the ability to flexibly and agilely adapt (adaptability) to the organization's changing environment, thus seeking its longterm survival (Gibson and Birkinshaw 2004). However, this is not the approach adopted in this study.

The scale for market-focused learning takes as a referent the work of Forsman (2011). Market-focused learning is measured by examining how firms can recognize that external knowledge can be advantageous for their management, incorporate it into the knowledge base available in the organization, and use it together with the internal knowledge generated within the firm to carry out innovations. The firm's innovation capability scale was inspired by the study of Weerawardena et al. (2006). We measured the intensity and novelty of the innovations commercialized by firms relative to their major competitors in the industry over the last 3 years. The reference to the major competitor in the industry allows minimizing the industry effect and decreasing the response's subjectivity, establishing a point of reference to make the comparison (Kraft 1990). Higher scores on that measurement scale capture a greater level of innovative activity with a greater degree of incorporated intensity and novelty relative to the firm's major competitors during the

Table 1 Measurement results

\begin{tabular}{|c|c|c|c|}
\hline Factor & Description & $\lambda$ & $t$-value \\
\hline \multirow{3}{*}{$\begin{array}{l}\text { Market-focused learning (first-order) } \\
\mathrm{AVE}=0.84 \\
\mathrm{CR}=0.94\end{array}$} & Ability to identify relevant market knowledge & 0.90 & 34.47 \\
\hline & Ability to internalize new market knowledge & 0.93 & 81.02 \\
\hline & Ability to exploit new knowledge for innovation & 0.92 & 59.63 \\
\hline \multirow{4}{*}{$\begin{array}{l}\text { Exploitation (first-order) } \\
\mathrm{AVE}=0.69 \\
\mathrm{CR}=0.90\end{array}$} & Try to maximize the satisfaction of our customers with the current offer & 0.76 & 16.43 \\
\hline & Constantly seek to improve the technical quality of our offer & 0.87 & 39.14 \\
\hline & Continuously improve the reliability of our products and services & 0.88 & 45.44 \\
\hline & Optimize the current offer to keep our customers satisfied & 0.82 & 22.09 \\
\hline \multirow{6}{*}{$\begin{array}{l}\text { Exploration (first-order) } \\
\mathrm{AVE}=0.63 \\
\mathrm{CR}=0.91\end{array}$} & Seek creative ways to meet customer needs & 0.80 & 27.47 \\
\hline & Search for new technological solutions & 0.84 & 35.83 \\
\hline & Sustaining success in the ability to explore new technologies & 0.87 & 42.78 \\
\hline & Create innovative products or services & 0.81 & 24.50 \\
\hline & Proactively target new customer groups & 0.74 & 17.84 \\
\hline & To venture into new market segments & 0.70 & 16.74 \\
\hline \multirow{2}{*}{$\begin{array}{l}\text { Organizational ambidexterity (second-order) } \\
\mathrm{AVE}=0.52 \\
\mathrm{CR}=0.92\end{array}$} & Exploitation $\leftarrow$ ambidexterity & 0.83 & 25.54 \\
\hline & Exploration $\leftarrow$ ambidexterity & 0.93 & 93.00 \\
\hline \multirow{6}{*}{$\begin{array}{l}\text { Innovation capability (first-order) } \\
A V E=0.85 \\
C R=0.97\end{array}$} & Our new products and services are more innovative than those of our competitors & 0.89 & 35.91 \\
\hline & Customers often perceive our innovations as very new & 0.91 & 61.16 \\
\hline & $\begin{array}{l}\text { We market innovations with a higher degree of novelty incorporated than our } \\
\text { competitors }\end{array}$ & 0.95 & 85.94 \\
\hline & We market more innovations than our competitors & 0.94 & 82.63 \\
\hline & We develop more new products and services than our competitors & 0.91 & 50.63 \\
\hline & The firm innovates with more intensity than the competition & 0.94 & 65.68 \\
\hline Cash flow (objective performance) & $\begin{array}{l}\text { Objective data from the SABI database, which captures the average cash flow } \\
\text { obtained by the firm in the last } 3 \text { years }\end{array}$ & - & - \\
\hline
\end{tabular}

$A V E$ mean variance extracted, $C R$ composite reliability index 
last 3 years. Thus, relative measures facilitate the comparison of different performance indicators (Stanko et al. 2012). Likewise, the time frame ensures the quality of the information acquired (Santos-Vijande et al. 2016).

We measure cash flow with objective data from SABI (Sistema de Análisis de Balances Ibéricos) database and capture its average cash flow in the last 3 years (an objective measure of financial performance). The use of objective performance measures helps to have data from a different source than the same key informant. Furthermore, cash flow "is relatively free from the accounting manipulations often used to manage earnings or minimize corporate income taxes" (Vorhies et al. 2009, p. 1318). Finally, we also incorporated control variables such as firm size, measured as the natural logarithm of the number of employees, and sales turnover. These control variables are expected to affect the endogenous latent variables included in the model directly.

The questionnaire used in this study was pre-tested with the collaboration of two academics, two innovation experts, working in the private foundation that provided the population of innovative companies surveyed, and four CEOs of these companies. The pre-test participants reviewed the questionnaire to check whether respondents might have any difficulty in understanding the wording of the items and to avoid any ambiguity or possible misunderstanding of the meaning of the items used in the measurement scales.

\section{Results}

Our analyses are based on the use of SmartPLS 3 (Ringle et al. 2015). We employ PLS-SEM with SmartPLS 3 software (Ringle et al. 2015) for several reasons (Hair et al. 2017a, b, 2021): (i) our study is exploratory in nature, and we intend to develop new theory; (ii) there is no need under this technique to use a large number of observations; (iii) the data does not need to follow a normal distribution as it is a nonparametric technique; (iv) using PLS allows commonly achieving high levels of statistical power even with small samples; and (v) it can manage latent variables with multiitem measures and single-item measures. In addition, using PLS-SEM, we intend to go beyond the limitations of the primarily exploratory first-generation multivariate methods such as cluster analysis, exploratory factor analysis, and multidimensional scaling. In the following, we employ the methodological procedures suggested by Hair et al. (2017a, b) to examine the measurement and structural models.

\section{Measurement model}

The psychometric properties (reliability, convergent validity, and discriminant validity) of the measurement scales show that all the items are accurate indicators of the latent variables (Table 1). All the loadings are above 0.7 and the associated $t$-value bootstrap, which is computed using 5000 subsamples (190 cases), is significant according to established procedures. The average variance extracted (AVE) values range from 0.52 to 0.85 and the composite reliability index (CRI) values from 0.90 to 0.97 . Discriminant validity was demonstrated. First, by checking that AVE's square root for each latent variable pair exceeds the correlation between those variables. Second, we also assess the heterotrait-monotrait ratio (HTMT) of the correlations, and all the values are below the 0.90 value. Table 2 shows the correlation matrix, means, standard deviations, and square root of the AVE of the latent variables in the conceptual model.

\section{Structural model}

We now examine the structural model estimates (Hair et al. 2017a, b, 2021). At this point, the evaluation criteria for PLS-SEM results are (a) the coefficient of determination $\left(R^{2}\right)$, (b) the Stone-Geisser criterion $\left(Q^{2}\right)$, and (c) the path coefficients and their associated $t$-value bootstrap (Table 3 ). The level of significance for such $t$-value bootstrap is computed using 5000 subsamples (190 cases). We also carried
Table 2 Descriptive statistics and correlations

\begin{tabular}{lllllll}
\hline & 1 & 2 & 3 & 4 & 5 & 6 \\
\hline 1. Organizational ambidexterity & 0.72 & & & & & \\
2. Market-focused learning & $0.62^{* * *}$ & 0.92 & & & & \\
3. Innovation capability & $0.59^{* * *}$ & $0.50^{* * *}$ & 0.92 & & & \\
4. Cash flow & $0.10^{\text {n.s. }}$ & $0.09^{\text {n.s. }}$ & $0.13^{*}$ & N.A. & & \\
5. Employees & $-0.08^{\text {n.s. }}$ & $-0.09^{\text {n.s. }}$ & $0.03^{\text {n.s. }}$ & $0.49^{* * *}$ & N.A. & \\
6. Sales volume & $-0.02^{\text {n.s. }}$ & $-0.08^{\text {n.s. }}$ & $0.03^{\text {n.s. }}$ & $0.24 * * *$ & $0.62^{* * *}$ & N.A. \\
Mean & 5.76 & 5.28 & 4.91 & $1,110,348.56$ & 1.46 & 0.55 \\
Standard deviation & 0.82 & 1.09 & 1.44 & $4,098,993.33$ & 2.24 & 0.75 \\
\hline
\end{tabular}

The square root of the AVE is in italics on the diagonal. The correlations are below the diagonal N.A. not applicable $* * * p<0.01 ; * * p<0.05 ; * p<0.10$ 
Table 3 Structural results



n.s. non-significant

$* * * p<0.01 ; * * p<0.05 ; * p<0.10$

out a post hoc power analysis with $\mathrm{G}+$ Power 3 statistical program that reveals that the structural model's power value and the sample we work with exceeds the 0.80 threshold. In Table 3, one observes that $R^{2}$ values for ambidexterity (0.40), innovation capability (0.39), and cash flow (0.25) are not below the 0.10 criteria (Hair et al. 2017a, b, 2021). The PLS-SEM blindfolding procedure shows that Q2 values range from 0.19 to 0.31 , which are larger than zero and indicate acceptable predictive relevance levels. Please see the Appendix for further details about the structural/inner model and insights on the difference between structural equation modeling and regression.

Regarding the hypothesized relationships (Table 3), the results show that market-focused learning has a significant direct effect both on organizational ambidexterity (H1: path coefficient $=0.63 ; p<0.01)$ and innovation capability (H2: path coefficient $=0.21 ; p<0.05)$, although the former direct effect is stronger than the latter. These results support our conceptual model about the relevance of market-focused learning for organizational ambidexterity. It also coincides with scholars that understand market-focused learning capability as a mechanism that allows a firm to be aware of market opportunities, innovate at a higher rate than its competitors, and favor the firm's innovation newness with its new products and processes (Kaleka and Morgan 2019).

Concerning H3, organizational ambidexterity positively influences innovation capability (path coefficient $=0.48$; $p<0.01$ ). This finding supports O'Reilly and Tushman's (2011) arguments that understand organizational ambidexterity as a dynamic capability that allows firms to reconfigure, adapt, and integrate organizational skills and resources to adjust to ever-changing environments. As expected, innovation capability likewise improves the firm's cash flow (H4: path coefficient $=0.12 ; p<0.01$ ). This result is in line with the notion that the firm's innovation capability can provide a unique value experience to the customer base with a product and service portfolio finely aligned with market expectations and latent needs (Prahalad and Krishnan 2008).

Regarding the multi-group analysis, we are interested in examining whether the model's effects differ significantly in low-end markets from non-low-end markets. We define the grouping variable with the following item: "In our firm, concentrating on core functionalities and reducing costs of innovation is a priority to access new market segments with lower WTP". We strictly adhere to Reinhardt's et al. (2018) view on frugal innovation. Our results also reveal that the sampled firms developing frugal innovation show significantly higher levels of innovation capability than those focusing on non-frugal innovation. Accordingly, these firms strive to adapt innovation core functions to the unique characteristics of this market segment. Key informants had to answer yes or no to that item. We employ a multiple methods approach: a permutation test; PLS-MGA; a parametric test; and Welch-Satterthwaite $t$-test (Hair et al. 2017a, b, 2021). Tables 4 and 5 show the multi-group analysis results (H5-H6) and provide further valuable insights. First, the impact of market-focused learning on innovation capability is significantly higher when firms operate in low-end markets ( $\mathrm{H} 5_{\text {low-end markets: }}$ : path coefficient $=0.46 ; p<0.01$ ) than when firms operate in non-low-end markets ( $\mathrm{H} 5$ non-low-end markets: path coefficient $=-0.09$; non-significant). The reason for this might be that firms that are interested in creating lowcost products for low-end markets find it more useful to compete with market-focused learning as a means for creating and marketing new products, processes, and systems to provide solutions that are affordable for low-income consumers. 
Table 4 Multi-group structural results

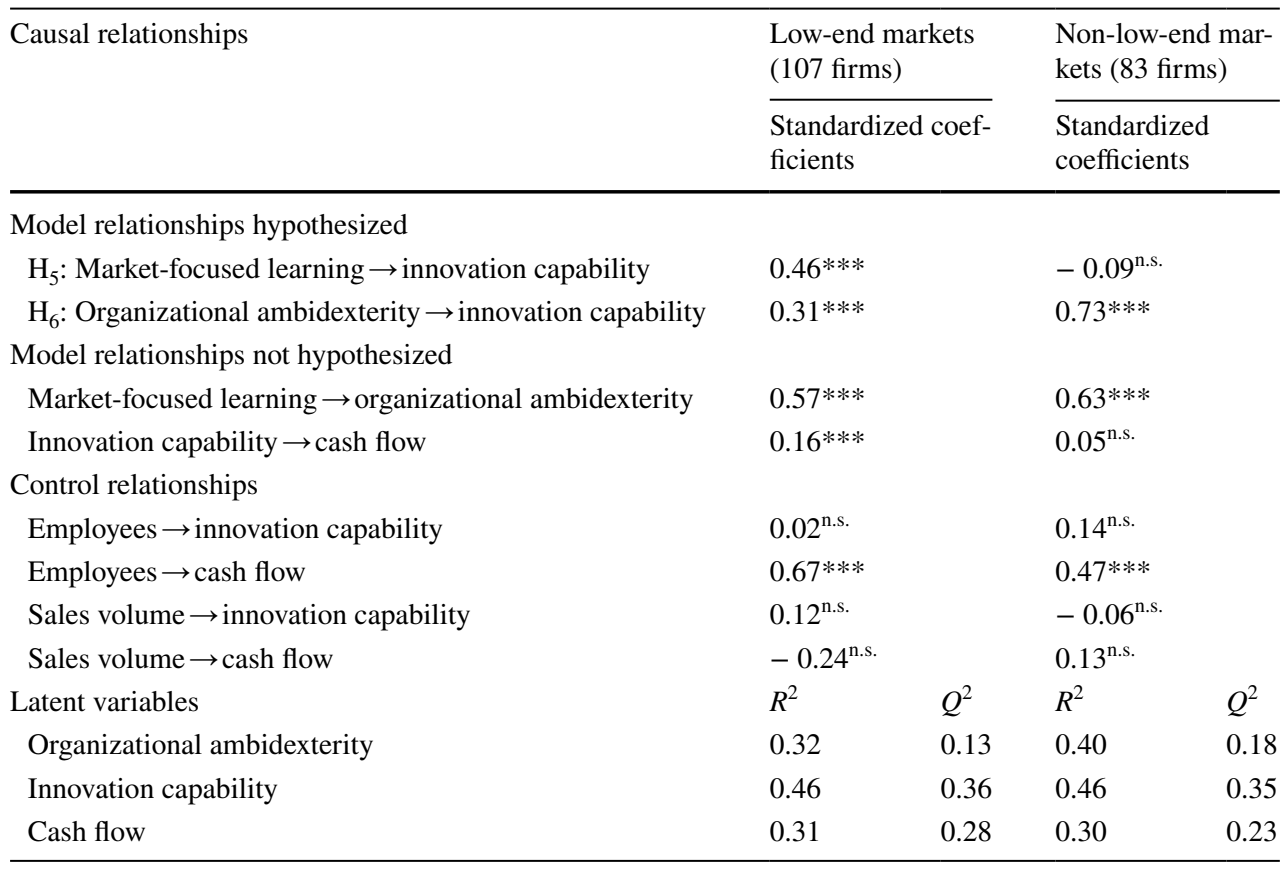

n.s. non-significant

$* * * p<0.01 ; * * p<0.05 ; * p<0.10$

Table 5 Multi-group results

Causal relationships

\begin{tabular}{llll}
\multicolumn{2}{l}{ Low-end markets vs. non-low-end markets } & \\
\hline Permutation test & PLS-MGA & Parametric test & Welch-Sat- \\
$p$ values & $p$ values ${ }^{\text {(a) }}$ & $p$ values & terthwaite \\
& & $t$-test \\
& & $p$ values
\end{tabular}

Model relationships hypothesized

$\mathrm{H}_{5}$ : Market-focused learning $\rightarrow$ innovation capability

$\mathrm{H}_{6}$ : Organizational ambidexterity $\rightarrow$ innovation capability

Model relationships not hypothesized

Market-focused learning $\rightarrow$ organizational ambidexterity

Innovation capability $\rightarrow$ cash flow

\begin{tabular}{llll}
$0.01^{* *}$ & $1.00^{* * * *}$ & $0.00^{* * * *}$ & $0.01^{* *}$ \\
$0.02^{* *}$ & $0.01^{* *}$ & $0.01^{* *}$ & $0.01^{* *}$ \\
& & & \\
$0.54^{\text {n.s. }}$ & $0.27^{\text {n.s. }}$ & $0.56^{\text {n.s. }}$ & $0.55^{\text {n.s. }}$ \\
$0.25^{\text {n.s. }}$ & $0.83^{\text {n.s. }}$ & $0.30^{\text {n.s. }}$ & $0.33^{\text {n.s. }}$ \\
\hline
\end{tabular}

PLS-MGA represents a one-tailed test. Therefore, by taking 1- $p$ value we can also assess whether the path coefficient in the second group is larger than in the first group (Hair et al. 2017a, b).

n.s. non-significant

$* * * * p=0.00 ; * * * p<0.01 ; * * p<0.05 ; * p<0.10$

Second, the influence of organizational ambidexterity on innovation capability is significantly more intense when firms operate in non-low-end markets $\left(\mathrm{H} 6_{\text {non-low-end markets }}\right.$ : path coefficient $=0.73 ; p<0.01)$ than when firms try to innovate for low-end markets ( $\mathrm{H6}_{\text {low-end markets: }}$ path coefficient $=0.31 ; p<0.01)$. A reasonable explanation for this is that firms that do not provide low-price products and services for the low-end market need different capabilities than for frugal innovation (Reinhardt et al. 2018). Specifically, our research reveals that firms focused on frugal innovation consider more useful market-focused learning than organizational ambidexterity, and this is indicative they consider this option as a means to successfully develop frugal innovations, facilitating, in turn, those customers with a lower willingness to pay to enter the market. Consequently, these results point out that firms focused on frugal innovation differently prioritize market-focused learning and ambidexterity capabilities to enhance how they carry out innovation capability compared to firms focused on non-frugal innovation. 


\section{Additional checks}

We have employed additional methods to check for nonlinear effects using the approach suggested by Svensson et al. (2018) and Sarstedt et al. (2020b). First, we have used Ramsey's (1969) RESET through STATA 15.1 on the latent variable scores emanating from the original model's PLSSEM algorithm. This test reveals that the partial regression of cash flow on innovation capability $(F(3,185)=0.82$, Prob $>F=0.480$ ), nor the partial regression of innovation capability on market-focused learning and ambidexterity $(F$ $(3,184)=0.05$, Prob $>F=0.984)$ are subject to nonlinearities. Second, we have included in the PLS-SEM model the nonlinear quadratic effects of (1) market-focused learning on innovation capability, (2) ambidexterity on innovation capability, and (3) innovation capability on cash flow. The empirical results show that using a re-sampling method with 5000 subsamples (Hair et al. 2017a, b, 2021), none of those mentioned above nonlinear effects is significant (Table 6). Thus, we can conclude that the linear effects PLS-SEM model is robust.

In addition, collinearity problems should be assessed in a structural model under PLS-SEM, and thus we run a full collinearity test (Kock and Lynn 2012; Kock 2015; Hair et al. 2017a, b, 2021). The empirical results reveal that none of the latent variables in the structural model had variance inflation factors (VIFs) above five, and we can assert that there are no problems with potential collinearity at this point.

\section{Discussion and conclusion}

There is an increasing polarization of wealth and a cumulative number of consumers with minimal spending capacity in developed economies, so firms must take seriously that in this context frugal innovation may provide significant growth potential and business opportunities (Reinhardt et al. 2018; Albert 2019; Hossain 2020; IMF 2020).

This paper examines the critical role of two key organizational capabilities, market-focused learning and organizational ambidexterity to develop a firm's innovation capability in a low-end and non-low-end context, and the impact of firm's innovation capability on cash flow. The research combines survey responses of managing directors with objective performance data, which reinforces the validity of our results. Our study responds to recent literature calls (Reinhardt et al. 2018; D'Angelo and Magnusson 2020; Iqbal et al. 2021) to identify the organizational capabilities that enhance the firms' ability to develop frugal innovations in developed countries. In this way, firms are in a better condition to serve the rising number of consumers with a low purchasing power and at risk of poverty that demand new products and services in developed countries (Winkler et al. 2020). In this respect, our study also provides useful insights into how firms can contribute and help transition towards improved social, economic, and ecological sustainability, as frugal innovation has important implications in this respect.

Specifically, firms that include frugal innovation in their market offerings emphasize providing core functionalities with cost-saving opportunities, reducing the spending of low-end consumers (with an inherent frugal saving orientation), and thus promoting their standard of living (Reinhardt et al. 2018; Clausen and Ficther 2019; Winkler et al. 2020; Saha et al. 2021).

The implications of frugal innovation on economic sustainability result from the firm's ability to provide products and services with high value for low-income consumers as a result of giving a favorable cost-benefit ratio solution, eliminating superfluous and complex features, thus expanding the firm's customer base and ultimately its sales and profits (Clausen and Ficther 2019; Köhler et al. 2019). Firms that opt for this type of innovation can become even more efficient in using their resources, which often tend to be finite in resource-scarce environments (Bocken et al. 2014; Amankwah-Amoah et al. 2019). By focusing the attention on ecological sustainability, frugal innovation can have a low impact on the environment and, therefore, be considered eco-friendly, even promoting a more sustainable society (Van den Bergh et al. 2011; Albert 2019).

From the side of low-income consumers, they can be regarded "as agents for change with potentially far-reaching influence on business strategy and businesses' behavior" (Elf et al. 2021, p. 1038), which are also willing to buy as regular buyers new products and services, impelling prosperity and growth for firms (Prahalad 2019). From the side of businesses, providing frugal innovations within their market offerings to low-income consumers means influencing them to consume better and enhance their eco-friendly
Table 6 Assessment of nonlinear effects

\begin{tabular}{llll}
\hline Nonlinear relationships & $\begin{array}{l}\text { Standardized coef- } p \text { value } \\
\text { ficients }\end{array}$ & $\mathrm{f} 2$ \\
\hline $\begin{array}{l}\text { Market-focused learning } \times \text { market-focused learning } \rightarrow \text { innova- } \\
\text { tion capability }\end{array}$ & -0.031 & 0.704 & 0.002 \\
$\begin{array}{l}\text { Ambidexterity } \times \text { ambidexterity } \rightarrow \text { innovation capability } \\
\text { Innovation capability } \times \text { innovation capability } \rightarrow \text { cash flow }\end{array}$ & 0.001 & 0.981 & 0.000 \\
\hline
\end{tabular}


consumption patterns, thus contributing firms "to sustainable development by extending their business strategies" (Elf et al. 2021, p. 1038).

However, some studies contend that frugal innovation may entail threats to sustainability such as (1) the unsustainable ecological and social extraction of raw materials or manufacturing due to the extreme pursuit of cost savings (Hossain 2018); (2) an excess of resource consumption and waste generation due to the increased demand and shorter life cycles of very cheap products, or sachet packaging of bulk products (Rosca et al. 2017). In these cases, a dilemma arises between the deterioration of environmental sustainability due to increased demand for frugal innovation and the improvement of social sustainability that frugal innovation generates (greater inclusion, improved well-being, better livelihoods, better health, and poverty reduction). Moreover, frugal innovation can also lead to (3) the disposal of old and obsolete goods as new and cheaper ones become available, again multiplying waste generation (Albert 2019); or (4) the possible cannibalization of the firm's high-end offering by the cheaper innovation, especially if the frugal innovation simply lies in lowering the price by reducing highly specialized functions, which would lead to a reduction in total sales volume and could affect the firm's brand image (Wohlfart et al. 2016).

Despite these concerns, leading authors on frugal innovation state that "the transition to a more balanced interplay of environmental and economic systems can be achieved through closing-the-loop of production patterns within an economic system. But such a transition will require innovation, and moreover an approach to innovation that is itself frugal, flexible and inclusive. Thus, there are obvious and strong links between frugal innovation and the circular economy" (Prabhu 2018; 801). The circular economy is an essential strategy for achieving the desired sustainable development (Korhonen et al. 2018). Thus, the circular economy aims to maintain the value of products, materials and resources for as long as possible, returning them to the production cycle at the end of their use while minimizing waste generation (Pearce and Turner 1990). From this perspective, circular innovation seeks to generate zero waste by developing durable, recyclable, and reusable products (Varadarajan 2017).

In this line of reasoning, recent studies also underline that frugal innovation may reinforce the circular economy principles (Bocken 2020; Hossain et al. 2021) in several ways: (1) firms focusing on frugal innovation use in many cases locally available raw materials in their products, which reduces the need for transportation and hence lowers emissions; (2) firms focusing on frugal innovation also use in many cases re-used materials in production, which offsets waste generation in line with the notion of a circular economy; (3) similarly, these firms include recycling is an integral part of their business models; (4) moreover, frugal innovation slows resource consumption. In this respect, recent research confirms that companies that carry out environmental or frugal innovations are more likely to carry out circular economy actions (Arfaoui et al. 2021).

Therefore, we contend that the conception of frugal innovation in the context of the development of a Circular Economy, which constitutes a strategic objective for the European Union (CEAP 2020), can provide additional insights into the current shift for sustainability (Van Mossel et al. 2018; Clausen and Fichter 2019; Kohler et al. 2019; Hossain et al. 2021). In other words, frugal innovation can reinforce circular innovation and circular innovation principles can strengthen the sustainable impact of frugal innovation (Albert 2019; Hossain 2021; Saha et al. 2021). Thus, circular products are designed to achieve a longer life span, which prevents accelerated obsolescence and massive waste generation. Furthermore, the lower maintenance costs for the consumer that entails modularity in circular products, facilitating repairability, reinforces frugal innovation's economic and ecological sustainability. Circular innovation also focuses on using renewable energies, healthy and safe components, and the need to safeguard water as a unique resource, reducing in this way the potential damage of frugal innovation in terms of excessive resource consumption. Innovation strategies from a circular perspective are also often accompanied by developing new business models based on the collaborative economy and digital solutions for access to services. These business models themselves favor frugal innovation (fast, efficient, and affordable) and reinforce the firms' market image and differentiated positioning that could potentially be threatened by frugal innovation.

Our results provide empirical support that high levels of market-focused learning allow the exploitation of existing knowledge together with the exploration of new market opportunities, i.e., organizational ambidexterity. This finding is consistent with some previous works that put forward the idea that organizational ambidexterity, as a dynamic capability, is shaped by a firm's learning (Huang and Yong-Hui 2017; Van Welie et al. 2019), although empirical evidence in this respect is still scarce. Our study also emphasizes the vital role that market-focused learning has to provide valuable input to the intensity and novelty of a firm's innovation capability (Santos-Vijande et al. 2012a; Tamayo-Torres et al. 2016). This result contributes to the academic debate around the emergence of organizational innovation capability as a learning process in which marketplace knowledge is integrated into new products and processes that may help transition towards sustainability (Van Mossel et al. 2018).

As expected, organizational ambidexterity was also found to have a positive direct relationship with organizational innovation capability. This result draws our attention to the role that organizational ambidexterity has in predicting 
higher levels of innovation relative to the competition. Despite the conventional wisdom that links ambidexterity and innovation capability, empirical studies on this topic are still scarce (Benitez et al. 2018; Fu et al. 2021), moreover, referred to sustainable innovation (Peters and Buijs 2021). In addition, as innovation prevents natural obsolescence for a firm's market offering, and therefore, intervenes as a key factor in determining a firm's profitability and growth potential (Crossan and Apaydin 2010; Clausen and Ficther 2019), our study confirms that high levels of organizational innovation capability imply more elevated levels of cash flow.

The intensity of the effects of the key capabilities for innovation considered in our study differs between low-end markets and non-low-end markets. In particular, marketfocused learning is especially valuable for developing lowerpriced products that respond to customer needs in low-end markets. Thus, our study confirms for the first time that market-focused learning is a valuable organizational capability for addressing consumers with a low WTP.

Contrary to our expectations, we also found that the impact of organizational ambidexterity is more intense in non-low- than in low-end markets, although the theory suggests that its effect should be stronger on firms concentrating on strict cost controls and operations efficiency (Porter 1980). In any case, organizational ambidexterity is helpful in developing products and services for both non-low- and lowend markets, reinforcing the idea that ambidextrous firms can attain higher levels of innovation. From this perspective, organizational ambidexterity allows firms "to become more innovative and frugal in using their limited resources" (Amankwah-Amoah et al. 2019, p. 81) and being able to provide products and services that connect with low-end consumers that understand "environmentally friendly behaviors" (Elf et al. 2021, p. 1039). Therefore, although this result seems to make sense, we suspect that further efforts should be carried out to clarify it, considering that this is the first step to shed light on this issue.

This paper has several important implications for managers and policymakers and aims to contribute in several ways to the growing body of literature on frugal innovation. Our work provides insights into how manufacturing firms can develop frugal innovation. Managers should seek to develop a strong market-focused learning capability in their firms to facilitate frugal innovation. Therefore, market intelligence must be accompanied by the shared interpretation and vision of relevant knowledge to effectively exploit new knowledge. Recent studies also reveal that consumers like to describe themselves as frugal consumers rather than wasteful consumers and that frugality is one of the key reasons why individuals adopt pro-environmental behaviors (Triantafyllidis and Darvin 2021). From this perspective, policymakers should also bear in mind that "focusing on frugality can also be particularly fruitful in promoting sustainability with a wider population" (Gatersleben et al. 2019, p. 43). In addition, managers also need to understand that market-focused learning facilitates the development of ambidextrous strategies, which also have a strong effect on the innovativeness of firms. Thus, despite the difficulties inherent in combining more risky (exploration) or conservative (exploitation) strategies, the benefits for firms' innovativeness of organizational ambidexterity in low-end and especially non-low-end markets reinforce the relevance of this organizational capability to compete in the long run. Policymakers aiming to make the transition to a sustainable, low-income consumer-friendly economy need to understand the rationale for firms' innovation capabilities and encourage the development of relevant skills in all sectors.

Like any scientific work, this study has its limitations. First, we use cross-sectional data, which prevents us from asserting that causal relationships are stable in the long term. A longitudinal study would be an option to overcome this limitation and better understand whether different periods would yield similar results. Second, we use measurement scales to capture key informants' perceptions, except for the cash flow's final dependent variable. This is useful as it helps to have data from a different source than the same key informant, which in our study has 12.5 years of average experience in his/her position. The consideration of multiple respondents for each sampling unit would also be in future research a way to complement the obtained results as well as the replication of the study in various countries. Third, there were no problems with the common method variance as the study design (ex ante) and evaluations (ex post) carried out revealed that there were no limitations at this point; above all, considering that we additionally combined survey responses with objective data, increasing the confidence of the results (Podsakoff et al. 2012). Finally, we work with a sample of innovative firms, so it is risky to extrapolate the results to other samples with firm profiles that differ from those analyzed here. Therefore, there is a need to confirm these results in different study contexts and under distinct environmental circumstances.

\section{Appendix}

This work's relevant structural equation model, "also called the inner model in the context of PLS-SEM" (Hair et al. 2017a, p. 11), shows the relationships/paths between the latent variables. The structural/inner model in our study included three endogenous latent variables, including (a) organizational ambidexterity, explained by marketfocused learning, (b) innovation capability explained by market-focused learning, organizational ambidexterity, employees and sales volume, and (c) cash flow, explained by innovation capability, employees and sales volume. In 
this way, as the "basic PLS design assumes a recursive inner model that is subject to a predictor specification .... thus, the inner model constitutes a causal chain system (i.e., with uncorrelated residuals and without correlations between the residual term of a certain endogenous latent variable and its explanatory latent variables)" (Henseler et al. 2009, p. 285). Therefore, such predictor specification allows us to write in line with conventional descriptions of PLS (Henseler et al. 2009; Hair et al. 2017a, b) the following equation for the structural/inner model:

Organizational ambidexterity $_{t}=$ Market focused learning $_{t} * \beta_{1}$

Innovation capability ${ }_{t}=$ Market focused learning ${ }_{t} * \beta_{2}$

+ Organizational ambidexterity $_{t} * \beta_{3}$

+ Employees $_{t} * \beta_{4}+$ Sales volume $_{t} * \beta_{5}$

Cash flow $_{t}=$ Innovation capability $_{t} * \beta_{6}$

$$
+ \text { Employees }_{t} * \beta_{7}+\text { Sales volume }_{t} * \beta_{8} \text {. }
$$

In addition to this, Bollen and Pearl (2013, p. 310) succinctly highlight the difference between structural equation modeling and regression with an excerpt from Goldberger (1973, p. 2) that read as follows: "In a structural equation model each equation represents a causal link rather than a mere empirical association. In a regression model, on the other hand, each equation represents the conditional mean of a dependent variable as a function of explanatory variables."

More recently, Hair et al. (2019, p. 3) point out that the "PLS-SEM method is very appealing to many researchers as it enables them to estimate complex models with many constructs, indicator variables and structural paths without imposing distributional assumptions on the data. More importantly, however, PLS-SEM is a causal-predictive approach to SEM that emphasizes prediction in estimating statistical models, whose structures are designed to provide causal explanations". In this context, Iacobucci et al. (2007, p. 146) also explain the superiority of structural equation modeling in the following sense: "Fitting components of models simultaneously is always statistically superior to doing so in a piece meal fashion, for example to statistically control for and partial out other relationship. That is, the empirical results are not a coincidence or function of the data, as they are driven by the statistical theory that the simultaneously fit equations will dominate in producing more consistent estimates".

To conclude, Sarstedt et al. (2020a, p. 295) posit the following: "But relying on regression analyses has been subject to considerable criticism when estimating models with latent variables since they (1) treat elements of the effect chains (structural model relationships) as separate processes, and (2) ignore the effect of measurement error. These problems are exacerbated in conditional process analyses (moderated mediation) as the interaction effect strengthens the attenuating effect of measurement error".

Acknowledgements The authors gratefully acknowledge the valuable comments and suggestions from Professor Christian Ringle (the Hamburg University of Technology and a member of the team of SmartPLS 3 developers). All remaining errors are our own.

Funding This research has received financial support from the Spanish Ministry of Economy and Competitiveness under the 2019 Call for R\&D Projects (Project reference number: PID2019-105726RB-I00).

\section{Declarations}

Conflict of interest The authors declare that they have no conflict of interest.

\section{References}

Albert M (2019) Sustainable frugal innovation-the connection between frugal innovation and sustainability. J Clean Prod 237(117747):1-15

Amankwah-Amoah J, Danso A, Adomako S (2019) Entrepreneurial orientation, environmental sustainability and new venture performance: does stakeholder integration matter? Bus Strateg Environ 28(1):79-87

Andriopoulos C, Lewis MW (2009) Exploitation-exploration tensions and organizational ambidexterity: Managing paradoxes of innovation. Organ Sci 20(4):696-717

Arfaoui N, Le Bas C, Vernier MF, Vo LC (2021) Circular Economy Practices and Innovative Behaviors. Lessons from Empirical Research in the Chemical Industry. Electronic Working Paper Series. ESDES-Research Center. Lyon Catholic University

ATKearney (2007) Serving the low-income consumer. How to tackle this mostly ignored market. http://bit.ly/2LthTIJ

Benitez J, Castillo A, Llorens J, Braojos J (2018) IT-enabled knowledge ambidexterity and innovation performance in small U.S. firms: the moderator role of social media capability. Inf Manag 55(1):131-143

Bhatti Y, Basu RR, Barron D, Ventresca MJ (2018) Emerging concepts in innovation. In: Frugal innovation: models, means, methods. Cambridge University Press, pp 160-188

Birkinshaw J, Zimmermann A, Raisch S (2016) How do firms adapt to discontinuous change? Calif Manage Rev 58(4):36-58

Bocken N (2020) Circular economy: slowing resource flows and increasing value. In: The Circular Economy in the European Union. Springer, Cham, pp 117-129

Bocken NM, Short SW, Rana P, Evans S (2014) A literature and practice review to develop sustainable business model archetypes. J Clean Prod 65:42-56

Bollen KA, Pearl J (2013) Eight myths about causality and structural equation models. In: Handbook of causal analysis for social research.. Springer, Dordrecht, pp 301-328

CEAP (2020) Circular Economy Action Plan (CEAP) for a cleaner and more competitive Europe. Communication from the Commission to the European parliament, the Council, the European Economic and Social Committee and the Committee of the Regions. COM/2020/98 final 
Chebbi H, Yahiaoui D, Vrontis D, Thrassou A (2015) Building multiunit ambidextrous organizations-a transformative framework. Hum Resour Manage 54(S1):155-177

Chen Q, Liu Z (2018) How does openness to innovation drive organizational ambidexterity? The mediating role of organizational learning goal orientation. IEEE Trans Eng Manage 66(2):156-169

Christofi M, Vrontis D, Cadogan JW (2021) Micro-foundational ambidexterity and multinational enterprises: a systematic review and a conceptual framework. Int Bus Rev 30(1):101625

Clausen J, Fichter K (2019) The diffusion of environmental product and service innovations: driving and inhibiting factors. Environ Innov Soc Trans 31:64-95

Clauss T, Kraus S, Kallinger FL, Bican PM, Brem A, Kailer N (2020) Organizational ambidexterity and competitive advantage: the role of strategic agility in the exploration-exploitation paradox. Journal of Innovation \& Knowledge (in Press)

Cohen WM, Levinthal DA (1990) Absorptive capacity: a new perspective on learning and innovation. Adm Sci Q 35(1):128-154

Crossan MM, Apaydin A (2010) A multi-dimensional framework of organizational innovation: a systematic review of the literature. J Manag Stud 47(6):1154-1191

Damanpour F, Sanchez-Henriquez F, Chiu HH (2018) Internal and external sources and the adoption of innovations in organizations. Br J Manag 29(4):712-730

D'Angelo V, Magnusson M (2020) A bibliometric map of intellectual communities in frugal innovation literature. IEEE Trans Eng Manag 68(3):653-666

Ekins P, Zenghelis D (2021) The costs and benefits of environmental sustainability. Sustain Sci 16(3):949-965

Elf P, Isham A, Gatersleben B (2021) Above and beyond? How businesses can drive sustainable development by promoting lasting pro-environmental behaviour change: an examination of the IKEA Live Lagom project. Bus Strateg Environ 30(2):1037-1050

Ernst H, Kahle HN, Dubiel A, Prabhu J, Subramaniam M (2015) The antecedents and consequences of affordable value innovations for emerging markets. J Prod Innov Manag 32(1):65-79

Fang C, Lee J, Schilling MA (2010) Balancing exploration and exploitation through structural design: the isolation of subgroups and organizational learning. Organ Sci 21(3):625-642

Faridian PH, Neubaum DO (2021) Ambidexterity in the age of asset sharing: development of dynamic capabilities in open source ecosystems. Technovation 99:102125

Ferreira J, Coelho A, Moutinho L (2020) Dynamic capabilities, creativity and innovation capability and their impact on competitive advantage and firm performance: the moderating role of entrepreneurial orientation. Technovation 92:102061

Forsman H (2011) Innovation capacity and innovation development in small enterprises. A comparison between the manufacturing and service sectors. Res Policy 40(5):739-750

Fu X, Luan R, Wu HH, Zhu W, Pang J (2021) Ambidextrous balance and channel innovation ability in Chinese business circles: the mediating effect of knowledge inertia and guanxi inertia. Ind Mark Manag 93:63-75

Gatersleben B, Murtagh N, Cherry M, Watkins M (2019) Moral, wasteful, frugal, or thrifty? Identifying consumer identities to understand and manage pro-environmental behavior. Environ Behav 51(1):24-49

Gebhardt GF, Farrelly FJ, Conduit J (2019) Market intelligence dissemination practices. J Mark 83(3):72-90

Gibson CB, Birkinshaw J (2004) The antecedents, consequences, and mediating role of organizational ambidexterity. Acad Manag $\mathbf{J}$ 47(2):209-226

Goldberger AS (1973) Structural equation models: an overview. In: Goldberger AS, Duncan OD (eds) Structural equation models in the social sciences. Seminar Press, New York, pp 1-18
Gordon L, Hodgson A (2017) Doing business at the bottom of the pyramid is not all about low-income countries. Euromonitor International. http://bit.ly/2H6UOHx

Hair JF Jr, Hult GTM, Ringle CM, Sarsted M (2017a) A primer on partial least squares structural equation modeling (PLS-SEM). Sage Publications, London

Hair JF Jr, Sarstedt M, Ringle CM, Gudergan SP (2017b) Advanced issues in partial least squares structural equation modeling. Sage Publications, London

Hair JF, Risher JJ, Sarstedt M, Ringle CM (2019) When to use and how to report the results of PLS-SEM. Eur Bus Rev 31(1):2-24

Hair JF Jr, Hult GTM, Ringle CM, Sarstedt M (2021) A primer on partial least squares structural equation modeling (PLS-SEM), 3rd edn. Sage Publications, London

Henseler J, Ringle CM, Sinkovics RR (2009) The use of partial least squares path modeling in international marketing. In: New challenges to international marketing. Emerald Group Publishing Limited

Herzallah A, Gutierrez-Gutierrez LJ, Munoz Rosas JF (2017) Quality ambidexterity, competitive strategies, and financial performance: an empirical study in industrial firms. Int J Oper Prod Manag 37(10):1496-1519

Hossain M (2018) Frugal innovation: a review and research agenda. J Clean Prod 182:926-936

Hossain M (2020) Frugal innovation: conception, development, diffusion, and outcome. J Clean Prod 121456:1-10

Hossain M (2021) Frugal innovation and sustainable business models. Technol Soc 64:101508

Hossain M, Simula H, Halme M (2016) Can frugal go global? Diffusion patterns of frugal innovations. Technol Soc 46:132-139

Hossain M, Levänen J, Wierenga M (2021) Pursuing frugal innovation for sustainability at the grassroots level. Manag Organ Rev. https://doi.org/10.1017/mor.2020.53

Huang JW, Yong-Hui L (2017) The mediating role of ambidextrous capability in learning orientation and new product performance. J Bus Ind Market 32(5):613-624

Iacobucci D, Saldanha N, Deng X (2007) A meditation on mediation: evidence that structural equations models perform better than regressions. J Consum Psychol 17(2):139-153

International Monetary Fund (IMF) (2020) IMF Annual Report. A year like no other. https://www.imf.org/external/pubs/ft/ar/2020/eng/

Iqbal Q, Ahmad NH, Halim HA (2021) Insights on entrepreneurial bricolage and frugal innovation for sustainable performance. Bus Strategy Dev 4:237-245

Jansen JJP, Tempelaar MP, van den Bosch FAJ, Volberda HW (2009) Structural differentiation and ambidexterity: the mediating role of integration mechanisms. Organ Sci 20(4):797-811

Kaleka A, Morgan NA (2019) How marketing capabilities and current performance drive strategic intentions in international markets. Ind Mark Manag 78:108-121

Khan R (2016) How frugal innovation promotes social sustainability. Sustainability 8(1034):1-29

Kock N (2015) Common method bias in PLS-SEM: A full collinearity assessment approach. Int J e-Collab 11(4):1-10

Kock N, Lynn GS (2012) Lateral collinearity and misleading results in variance-based SEM: an illustration and recommendations. J Assoc Inf Syst 13(7):546-580

Köhler J, Geels FW, Kern F, Markard J, Onsongo E, Wieczorek A et al (2019) An agenda for sustainability transitions research: state of the art and future directions. Environ Innov Soc Trans 31:1-32

Korhonen J, Honkasalo A, Seppälä J (2018) Circular economy: the concept and its limitations. Ecol Econ 143:37-46

Kraft K (1990) Are product and process innovations independent of each other? Appl Econ 22(8):1029-1038 
Lapersonne A, Sanghavi N, De Mattos C (2015) Hybrid strategy, ambidexterity and environment: toward an integrated typology. Univers J Manag 3(12):497-508

Liang X, Frösén J (2020) Examining the link between marketing controls and firm performance: the mediating effect of marketfocused learning capability. J Bus Res 109:545-556

Lindell MK, Whitney DJ (2001) Accounting for common method variance in cross-sectional research designs. J Appl Psychol 86(1):114-121

Lubatkin MH, Simsek Z, Ling Y, Veiga JF (2006) Ambidexterity and performance in small-to medium-sized firms: the pivotal role of top management team behavioral integration. J Manag 32(5):646-672

Malik A, Sinha P, Pereira V, Rowley C (2019) Implementing globallocal strategies in a post-GFC era: creating an ambidextrous context through strategic choice and HRM. J Bus Res 103:557-569

March JG (1991) Exploration and exploitation in organizational learning. Organ Sci 2(1):71-87

Mendoza-Silva A (2020) Innovation capability: a systematic literature review. Eur J Innov Manag (in Press)

O'Callaghan P, Adapa LM, Buisman C (2020) How can innovation theories be applied to water technology innovation? J Clean Prod 122910:1-10

O'Reilly C, Tushman ML (2011) Organizational ambidexterity in action: how managers explore and exploit. Calif Manage Rev 53(4):5-22

Pearce D, Turner RK (1990) Economics of natural resources and the environment. Johns Hopkins University Press, Baltimore

Peters K, Buijs P (2021) Strategic ambidexterity in green product innovation: Obstacles and implications. Bus Strateg Environ. https:// doi.org/10.1002/bse.2881

Pinkse J, Bohnsack R (2021) Sustainable product innovation and changing consumer behavior: Sustainability affordances as triggers of adoption and usage. Bus Strategy Environ (Early View)

Podsakoff PM, Mackenzie SB, Podsakoff NP (2012) Sources of method bias in social science research and recommendations on how to control it. Ann Rev Sociol 63:539-569

Porter ME (1980) Competitive strategy: Techniques for analyzing industries and competitors. Free Press, New York

Prabhu J (2018) Frugal innovations for the circular economy: an epilogue. In: Resource Recovery from Waste. Routledge, pp 801-803

Prahalad D (2019) The New Fortune at the Bottom of the Pyramid. Strategy + Business, p 94. http://bit.ly/2Yck4S9

Prahalad CK, Krishnan MS (2008) The new age of innovation. McGraw-Hill Professional Publishing, New York

Ramsey JB (1969) Tests for specification errors in classical linear leastsquares regression analysis. J Roy Stat Soc: Ser B (methodol) 31:350-371

Reinhardt R, Gurtner S, Griffin A (2018) Towards an adaptive framework of low-end innovation capability-a systematic review and multiple case study analysis. Long Range Plan 51(5):770-796

Ringle CM, Wende S, Becker J-M (2015) "SmartPLS 3." Boenningstedt: SmartPLS GmbH, http://www.smartpls.com

Rosca E, Arnold M, Bendul JC (2017) Business models for sustainable innovation-an empirical analysis of frugal products and services. Journal Cleaner Production 162:S133-S145

Saha K, Dey PK, Papagiannaki E (2021) Implementing circular economy in the textile and clothing industry. Bus Strategy Environ 30(4):1497-1530

Santos-Vijande ML, López-Sánchez JA, González-Mieres C (2012a) Organizational learning, innovation and performance in KIBS. J Manag Organ 18(6):870-904

Santos-Vijande ML, López-Sánchez JA, Trespalacios-Gutiérrez JA (2012b) How organizational learning affects a firm's flexibility, competitive strategy, and performance. J Bus Res 65(8):1079-1089

Santos-Vijande ML, López Sánchez JÁ, Rudd J (2016) Front-Line employees' involvement in industrial service innovation: Impact of routes of co-creation on N.S. performance. J Acad Mark Sci 44(3):350-375

Sarstedt M, Hair JF Jr, Nitzl C, Ringle CM, Howard MC (2020a) Beyond a tandem analysis of SEM and PROCESS: use of PLSSEM for mediation analyses!. Int J Mark Res 62(3):288-299

Sarstedt M, Ringle CM, Cheah JH, Ting H, Moisescu OI, Radomir L (2020b) Structural model robustness checks in PLS-SEM. Tour Econ 26(4):531-554

Simao L, Franco M (2018) External knowledge sources as antecedents of organizational innovation in firm workplaces: a knowledge-based perspective. J Knowl Manag 22(2):237-256

Stanko MA, Molina-Castillo FJ, Munuera-Alemán JL (2012) Speed to market for innovative products: blessing or curse? J Prod Innov Manag 29(5):751-765

Svensson G, Ferro C, Høgevold N, Padin C, Varela JCS, Sarstedt M (2018) Framing the triple bottom line approach: Direct and mediation effects between economic, social and environmental elements. J Clean Prod 197:972-991

Tamayo-Torres I, Gutiérrez-Gutiérrez LJ, Llorens-Montes FJ, Martínez-López FJ (2016) Organizational learning and innovation as sources of strategic fit. Ind Manag Data Syst 116(8):1445-1467

Teece D, Peteraf M, Leih S (2016) Dynamic capabilities and organizational agility: risk, uncertainty, and Strategy in the innovation economy. Calif Manage Rev 58(4):13-35

Triantafyllidis S, Darvin L (2021) Mass-participant sport events and sustainable development: Gender, social bonding, and connectedness to nature as predictors of socially and environmentally responsible behavior intentions. Sustain Sci 16(1):239-253

Van den Bergh JC, Truffer B, Kallis G (2011) Environmental innovation and societal transitions: Introduction and overview. Environ Innov Soc Trans 1(1):1-23

Van Mossel A, van Rijnsoever FJ, Hekkert MP (2018) Navigators through the storm: a review of organization theories and the behavior of incumbent firms during transitions. Environ Innov Soc Trans 26:44-63

Van Welie MJ, Truffer B, Gebauer H (2019) Innovation challenges of utilities in informal settlements: combining a capabilities and regime perspective. Environ Innov Soc Trans 33:84-101

Varadarajan R (2017) Innovating for sustainability: a framework for sustainable innovations and a model of sustainable innovations orientation. J Acad Mark Sci 45(1):14-36

Venugopal A, Krishnan TN, Upadhyayula RS, Kumar M (2020) Finding the microfoundations of organizational ambidexteritydemystifying the role of top management behavioural integration. J Bus Res 106:1-11

Von Janda S, Kuester S, Schuhmacher MC, Shainesh G (2020) What frugal products are and why they matter: a cross-national multimethod study. J Clean Prod 246(118977):1-19

Vorhies DW, Morgan RE, Autry CW (2009) Product-market strategy and the marketing capabilities of the firm: impact on market effectiveness and cash flow performance. Strateg Manag J 30(12):1310-1334

Vorhies DW, Orr LM, Bush VD (2011) Improving customer-focused marketing capabilities and firm financial performance via marketing exploration and exploitation. J Acad Mark Sci 39(5):736-756

Vrontis D, Thrassou A, Santoro G, Papa A (2017) Ambidexterity, external knowledge and performance in knowledge-intensive firms. J Technol Transfer 42(2):374-388

Weerawardena J (2003) The role of marketing capability in innovationbased competitive strategy. J Strateg Mark 11(1):15-36 
Weerawardena J, O'Cass A, Julian C (2006) Does industry matter? Examining the role of industry structure and organizational learning in innovation and brand performance. J Bus Res 59(1):37-45

Weerawardena J, Salunke S, Knight G, Mort GS, Liesch PW (2020) The learning subsystem interplay in service innovation in born global service firm internationalization. Ind Mark Manage 89:181-195

Weyrauch T, Herstatt C (2017) What is frugal innovation? Three defining criteria. J Frugal Innov 2(1):1-17

Wigboldus S, Jochemsen H (2021) Towards an integral perspective on leveraging sustainability transformations using the theory of modal aspects. Sustain Sci 16(3):869-887

Winkler T, Ulz A, Knöbl W, Lercher H (2020) Frugal innovation in developed markets - adaption of a criteria-based evaluation model. J Innov Knowl 5(4):251-259

Winterhalter S, Zeschky MB, Gassmann O (2016) Managing dual business models in emerging markets: an ambidexterity perspective. R\&D Manag 46(3):464-479
Wohlfart L, Bünger M, Lang-Koetz C, Wagner F (2016) Corporate and grassroot frugal innovation: a comparison of top-down and bottom-up strategies. Technol Innov Manage Rev 6(4):5-17

Wu H, Chen J (2020) International ambidexterity in firms' innovation of multinational enterprises from emerging economies: an investigation of TMT attributes. Balt J Manag 15(3):431-451

Yang D, Li L, Jiang X, Zhao J (2020) The fit between market learning and organizational capabilities for management innovation. Ind Mark Manage 86:223-232

Zhang H, Fang W, Cui A (2015) Balancing market exploration and market exploitation in product innovation: a contingency perspective. Int J Res Mark 32(3):297-308

Publisher's Note Springer Nature remains neutral with regard to jurisdictional claims in published maps and institutional affiliations. 